\title{
Improvement of quality of state customs services based on development of labor potential of customs officials
}

\author{
Konstantin Trubitsyn \\ Samara State Technical University \\ Samara, Russia \\ Trubitsyn.KV@samgtu.ru
}

Elena Mitrofanova

State University of Management

Moscow, Russia

elmitr@mail.ru

\author{
Viktor Khriashchev \\ Samara State Technical University \\ Samara, Russia \\ vkhriashchev@gmail.com
}

\author{
Alexandra Mitrofanova \\ State University of Management \\ Moscow, Russia \\ alexamitr@gmail.com
}

\begin{abstract}
In current economic environment, it is necessary to revise the approach to state customs services. For this purpose, the authors introduced a new estimated indicator for activities of customs authorities - the quality of state customs services. The result showed necessity to study the relationship between the quality of customs services, provided by customs officials, and their labor potential. The main aim of research is studying improvement of the quality of state customs services based on development of the labor potential of customs officials. For implementation of performance targets, authors proposed a technique, based on the Kano's model. The authors developed two types of questionnaires - for the state customs services distribution according to the Kano model and for evaluation of each service quality. In addition, the authors proposed changes in the interacting processes among the participants of foreign economic activities and customs authorities. The methodology proposed appropriate priority directions of development and influence on the level of customer satisfaction (participants of foreign economic activities) and on the quality of services, provided through improving the labor potential of customs officials.
\end{abstract}

Keywords - labor economics, labor potential, service quality, state customs services, customs authorities, human resources

\section{INTRODUCTION}

The effective performance of customs authorities of the Russian Federation largely guarantees economic security of the country. The share of customs payments in federal budget reaches $50 \%$ [4], which imposes a certain responsibility on all categories of employees of customs authorities. Therefore, the eventual result of activity of customs authorities of Russia depends on activities of each employee and his labor potential.

Cooperation of customs authorities with participants of foreign economic activities becomes the most important factor for effective fulfillment of customs challenges to accelerate trade turnover, budget replenishment and guarantee of economic security of the country [1].

In current economic conditions, the quality of services is a competitive advantage for organizations or government agencies, while the main resource is staff. The result showed necessity to study the relationship between the quality of customs services provided by customs officials and their labor potential.

\section{THEORY}

\section{A. State customs services}

The customs system, realizing activities in new philosophy of customs and modern market economy, is able to offer services to both state and private sectors.

The state customs services (to wide extent) are socioeconomic benefit of customs activity [1]. In a narrower sense, state customs services are an action or sequence of actions implemented by special customs instruments (including customs procedures, technologies, formalities, etc.) with the purpose to increase the consumer benefits from foreign economic activities for the state and the participant of foreign economic activities.

According to the definition of Makrusev V.V., state customs services are a general vector of development of the customs system, which focused on improving of existing and creating new organizational, economic and technological instruments for the qualitative and effective implementation of state policy in the development of economy and foreign economic activities of Russia [1]. 
State customs services have a dual character. On the one hand, services are rendered to the state, and on the other hand - to the business.

At the same time, the consumer benefits for different services are distinguished. If for the participants of foreign economic activities, the main advantage is the costeffectiveness of the customs sector, then the effective control of foreign economic activities is a priority for the state.

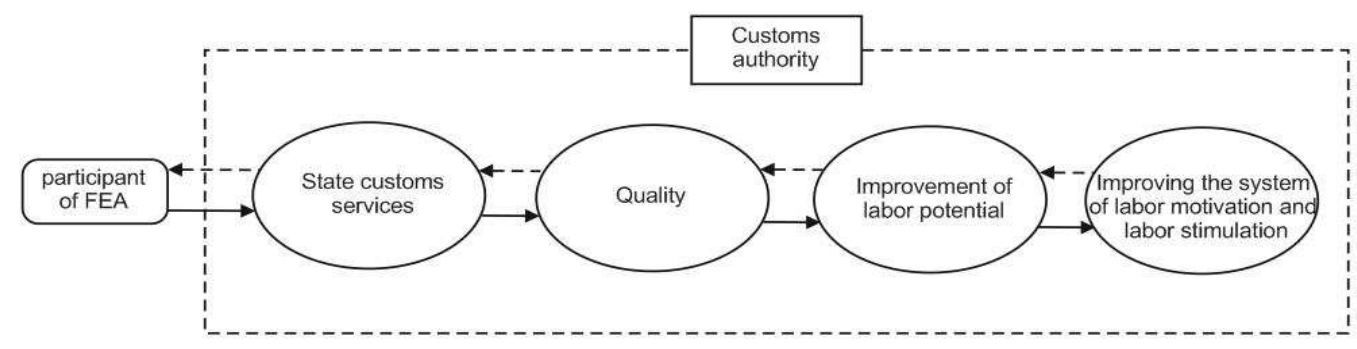

Fig. 1. The relationship between the labor potential of customs officials and quality of state customs services (source: compiled by the authors)

\section{B. Relationship between labor potential and state customs services}

As it was previously noted, in the current economic conditions it is necessary to review approach to state customs services. In this regard, it is necessary to introduce the concept of quality of rendering customs services as an evaluation indicator of customs authority activities.

The evaluation should be double-ended. On the one hand, state customs services are regulated by local regulations and standards. On the other hand, the evaluation should be carried out by the participants of foreign economic activities as the main consumers of services.

For participants of foreign economic activities, the structure of service management system may be secondary. The most important fact for them is not how the service process is organized, but primarily their benefits from services.
The prime factor of quality control of services is staff and their labor potential. The level of customer satisfaction depends on value of labor potential. Thus, authors suppose that through the improvement of labor potential of customs officials, the quality of customs services have to increase and vice versa.

Let us consider this process in more detail (Fig. 1).

A participant of foreign economic activities applies to the customs authority for a state customs services. After services were provided, assessment of customer satisfaction is given through feedback. If a participant of foreign economic activities is not satisfied, then one should evaluate customs officials' activity, and in case of systematic errors, the necessary adjustment is made: additional training and other actions aimed at increasing labor potential of customs officials (Fig. 2). This process works in the opposite direction too, when the quality of state customs services increases through the improvement of labor potential.

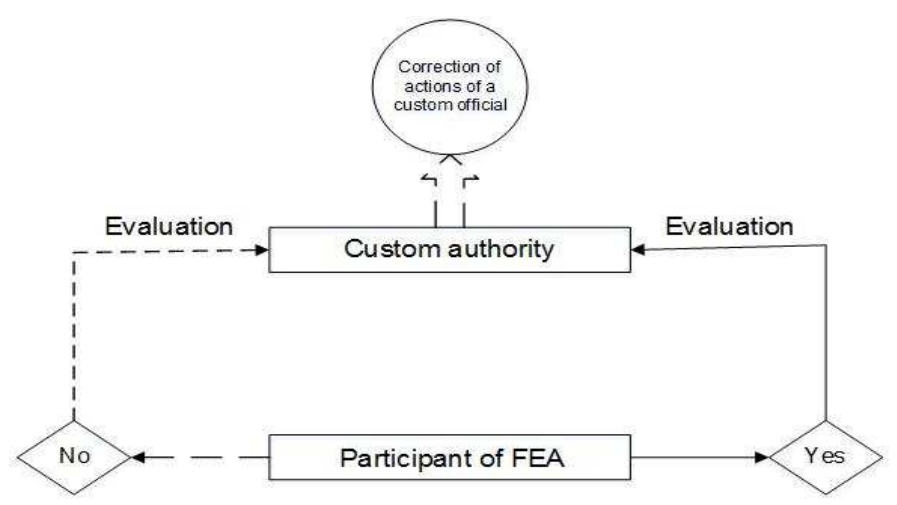

Fig. 2. Feedback from customers (participants of foreign economics activities) on the provided state customs services (source: compiled by the authors) 


\section{METHODOLOGY}

Analysis of foreign management and quality management literature [6-20] showed that the most widely-spread model displaying the assessment of product quality from the consumer's point of view is the quality profile model proposed by Nariaki Kano. Customer quality profile is the expected quality of a product or service that determines the degree of customer satisfaction [3]. The quality profile is a qualitative, descriptive model that establishes the dependence of customer satisfaction from the level of product or service quality [7]. This classification is used as the basis for the development of a product or service, especially to consider the quality function [9].

The Kano's model distinguishes three types of requirements: must-be, one-dimensional and attractive.

Must-be requirements: the must-be requirements are basic criteria of a product. Fulfilling the must-be requirements will only lead to a state of "not dissatisfied". If these requirements are not fulfilled, the customer will be extremely dissatisfied.
On the other hand, as the customer takes these requirements for granted, their fulfillment will not increase his satisfaction [6].

One-dimensional requirements: this is a set of quality indicators and their levels that are directly evaluated by the customers, and has prime influence on the value of product or service in their eyes. With regard to these requirements, customer satisfaction is proportional to the level of fulfillment - the higher the level of fulfillment, the higher the customer's satisfaction and vice versa. [6]

Attractive requirements: These requirements are the product criteria which have the greatest influence on how a customer will be satisfied with a given product. Attractive requirements are neither explicitly expressed nor expected by the customer. Fulfilling these requirements leads to more than proportional satisfaction. If they are not met, however, there is no feeling of dissatisfaction. [6]

Dependence of customer satisfaction on components of the quality profile is presented in Fig. 3.

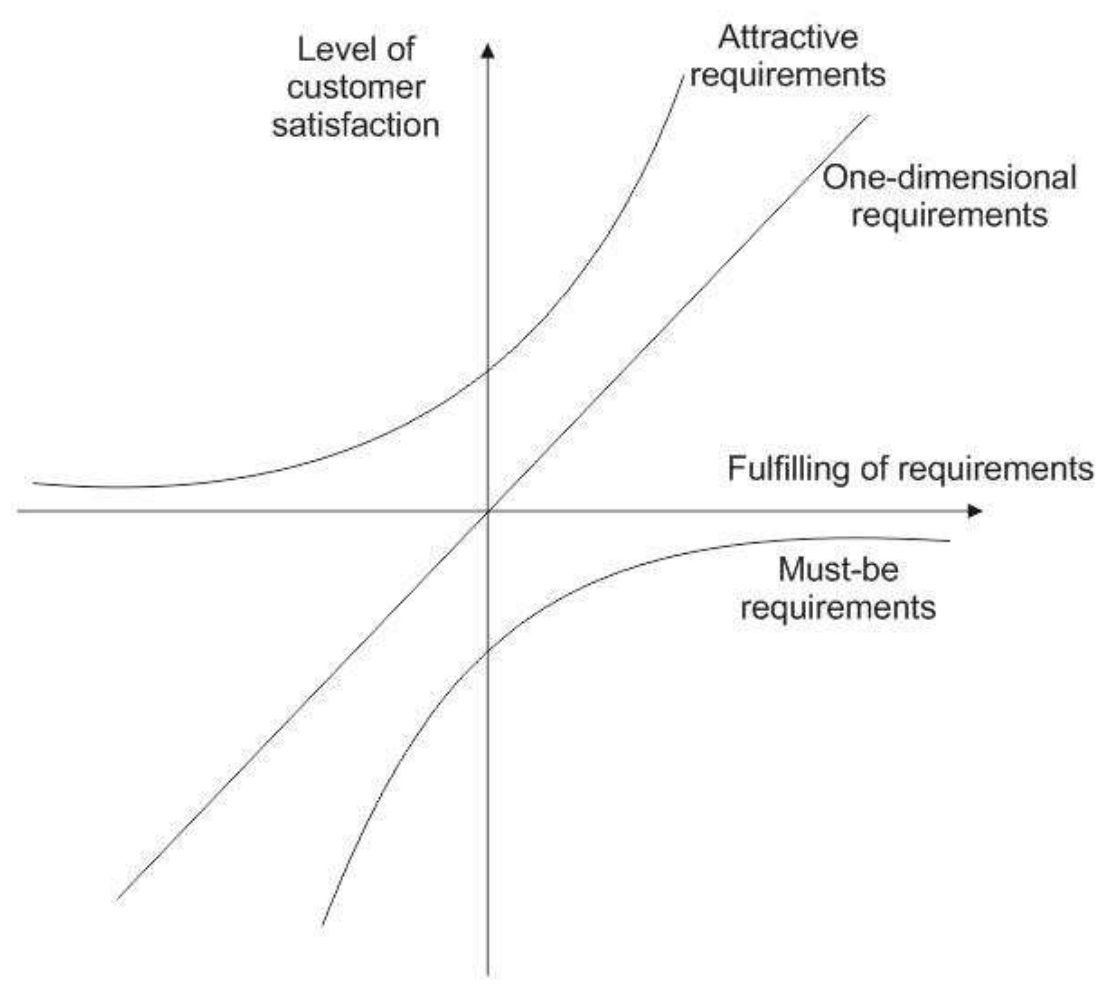

Fig. 3. Dependence between customer satisfaction and fulfilling of requirements [3] 


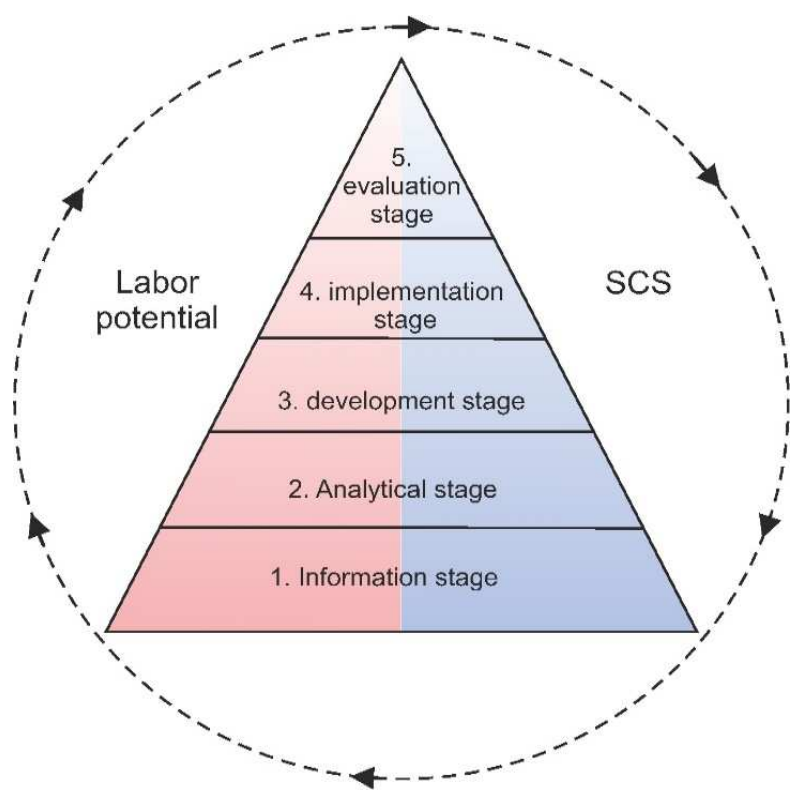

Fig. 4. The main stages of providing the state customs services (suggested by the authors)

As the state customs services are considered by authors in wide sense, it is not possible to identify certain quality characteristics of services. In this regard, it is necessary to modify the model that has been proposed before.

Let us divide the whole process of the provided customs services into five main stages (Fig. 4).

At the first stage, the data are collected both by the customs authority (expert evaluation method) and by the participants of foreign economic activities, as the primary consumers of the services (questionnaires and surveys).

At the second stage, it is necessary to divide the services according to the Kano's model. The result shows information about what services are needed for the participants of foreign economic activities, which have the most influence on their level of satisfaction, the presence of any desired, but not compulsive wishes. At this stage users can discover many types of services that are not currently available, but demanded by customers. If their implementation is possible by the customs authorities, the inclusion of such services in the list provided by customs authorities will increase their reputation in the eyes of the participants of foreign economic activities.

The third stage involves the development of methods of increasing labor potential, improving the system of motivation and stimulation of labor, the necessary legal and regulatory framework, regulations, standards and duty regulations.

The fourth stage is the introduction of previously developed documents and methodologies. At this stage, additional training and adjustments of customs official actions are carried out.

At the final stage of assessment, the analysis of changes of customer satisfaction is carried out. If customers are still not satisfied, then reasons of dissatisfaction are analyzed and the activity of customs officials is adjusted. Then the process repeat, beginning with the first stage.

\section{RESULTS}

The aim of this methodology is to improve the quality of state customs services on the basis of the labor potential development of customs officials.

Implementation of technique includes three stages:

- formation of the list of state customs services and their ranking by the degree of influence on the level of customer satisfaction (according to the Kano's model);

- $\quad$ status analysis of customs authorities' activities;

- improvement of the labor potential of customs officials.

The authors developed two types of questionnaires - for the state customs services distribution according to the Kano model and for evaluation of each service quality. The participants of foreign economic activities - respondents were tasked to rank services in terms of the importance for them and the degree of influence on their satisfaction.

In addition, respondents evaluated each service quality, assigning them appropriate value depending from existing level (range estimate from 1 to 9). This indicator evaluates the state of customs system resources for providing services to a participant of foreign economic activities.

Authors surveyed participants of foreign economic activities and the management of customs authorities, and after that state customs services and demand on services were determined according to the Kano's model (Table 1). 
TABLE I. The list of state customs services and degree of their importance for participants of foreign economic activities (source: compiled by the authors)

\begin{tabular}{|l|l|}
\hline Components of the quality profile & \multicolumn{1}{|c|}{ Service description } \\
\hline Must-be & $\begin{array}{l}\text { Informing and consulting of participants of foreign economic activities (1); } \\
\text { simplification of customs operations (5); software support adapted in customs } \\
\text { authorities (9); consideration of customers (participants of foreign economic } \\
\text { activities) resorts (10). }\end{array}$ \\
\hline One-directional & $\begin{array}{l}\text { E-declaration (3); pre-declaration (4); customs clearance on credit (6); } \\
\text { presentation of copies of customs declarations (7); presentation of information } \\
\text { about tax basis of customs tariff number (8); analysis of business activities of } \\
\text { the Region (15); optimization of rate policy (16); single approach in different } \\
\text { customs authorities (17). }\end{array}$ \\
\hline Attractive & $\begin{array}{l}\text { Adoption of pre-decision about classification of goods (2); operating analysis } \\
\text { of participant of foreign economic activities (13); licensing of } \\
\text { implementation for customs operations (11); granting of indulgence in } \\
\text { refunding customs payments (12); customs services for informing the } \\
\text { participants of foreign economic activities about foreign trade statistics (14). }\end{array}$ \\
\hline
\end{tabular}

In addition, the authors assessed state customs services as they may be necessary to promote participants of foreign economic activities, according to data compiled earlier (Fig. $5)$.

Thus, the presented analysis has made it possible to identify new services that are of interest to participants of foreign economic activities and can influence their level of satisfaction, and the current status of the state customs services quality is defined.

The methodology proposed by the authors appropriate priority directions of development and influence the level of customer satisfaction (participants of foreign economic activities) and the quality of services provided through improving the labor potential of customs officials.

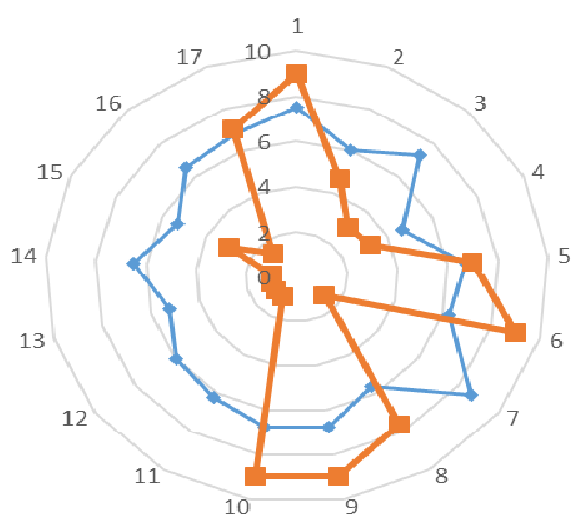

Fig. 5. Assessment of state customs services as may be necessary for participants of foreign economic activities (source: compiled by the authors): red line Participants in foreign trade activities; blue line - Customs

\section{CONCLUSION}

As it was previously noted, in current economic environment it is necessary to revise the approach to state customs services. For this purpose, the authors introduced a new estimated indicator for activities of customs authorities the quality of state customs services.

The prime factor of quality control of services is staff and their labor potential. The level of customer satisfaction depends on value of labor potential. Thus, authors suppose that through the improvement of labor potential of customs officials, the quality of customs services has to increase and vice versa.

For implementation of performance targets, the authors proposed a technique based on the Kano's model. In addition, there were proposed changes in the interacting processes among the participants of foreign economic activities and customs authorities.

The results of processing research data allow us to identify strengths and weaknesses of the system and identify key areas for the development of labor potential of customs officials. 
Analysis revealed that, in the context of a new customeroriented ideology formation, a number of problems arise concerning the relationship between the labor potential of customs officials and the quality of state customs services, which they provide:

- identification of internal strengths and weaknesses of the existing customs services system, as well as existing external opportunities and risks in the process of implementation of the business assistance ideology;

- modernization of the existing system for development of the labor potential of customs officials in the context of long-term goals, strategy, availability and allocation of resources;

- development of a logical harmonious system of labor potential management, differentiated by organizational levels;

- determination of criteria and methods for evaluation of economic and non-economic benefits from system implementation;

- determination of ways to promotion of competitiveness of the customs authorities in deciding the national agendas of economic advance and social wellbeing of society with unconditional statutory compliance of Russia.

The result of implementation of the modified Kano's model into the practice of customs officials' activities will be creation of an effective model for development of the labor potential of customs officials and, as a result, the improvement of quality of state customs services.

\section{References}

[1] V.V. Makrusev, "State customs services", Publishing house of the Russian customs academy, Is. 2, Moscow, 2011, p. 196.

[2] The order of the Federal Customs Service of Russia from 11.11.2005 №679 «On the procedure of development and approval of administrative regulations for the performance of public functions and administrative regulations for the provision of public services»

[3] O.P. Gludkin, N.M. Gorbunov, A.I. Gurov, U.V. Zorin, "Total Quality Control: college textbook", Radio and Signal communication, Moscow, 1999, p. 600.
[4] http://info.minfin.ru/fbdohod.php

[5] Khriashchev V.V., Trubitsyn K.V., "LABOR POTENTIAL OF CUSTOMS OFFICIALS: CONCEPT, STRUCTURE, EVALUATION", MANAGEMENT OF PERSONNEL AND INTELLECTUAL RESOURCES IN RUSSIA, Vol. 6, Is. 2, Moscow, pp. 5-10, 2017.

[6] Elmar Sauerwein , Franz Bailom, Kurt Matzler, Hans H. Hinterhuber, "THE KANO MODEL: HOW TO DELIGHT YOUR CUSTOMERS", Vol. I, International Working Seminar on Production Economics, Innsbruck: academic, pp. 313 -327, February 1996.

[7] M. Young, The Technical Writer's Handbook, Mill Valley, CA: University Science, 1989.

[8] Dauw-Song Zhu, Chih-Te Lin, Chung-Hung Tsai, Ji-Fu Wu A, "STUDY ON THE EVALUATION OF CUSTOMERS' SATISFACTION - THE PERSPECTIVE OF QUALITY", International Journal for Quality research, pp. 105-116, 2009.

[9] C.H. Yang, "The Refined Kano's Model and its Application", Total Quality Management, Vol. 16, No. 10, pp. 1127-1137, 2005.

[10] Kurt Matzler, H. Hans, Hinterhuber, "How to make product development projects more successful by integrating Kano's model of customer satisfaction into quality function deployment", Technovation, Volume 18, Issue 1, pp. 25-38, January 1998.

[11] M.A. Kaulio, "Customer, consumer and user involvement in product development: A framework and a review of selected methods", TOTAL QUALITY MANAGEMENT, Vol. 8, Is. 1, pp. 141-149, February 1998

[12] A. Griffin, Jr. Hauser, "The voice of the custo+mer", Marketing science, Vol. 12, Is. 1, pp. 1-27, 1993.

[13] L.K. Chan, M.L. Wu, "Quality function deployment: A literature review", EUROPEAN JOURNAL OF OPERATIONAL RESEARCH, Vol. 143, Is. 3, pp. 463-497, 2002.

[14] L.H. Chen, W.C. Ko, F.T. Yeh, ”Approach based on fuzzy goal programing annd quality function deployment for new product planning", EUROPEAN JOURNAL OF OPERATIONAL RESEARCH, Vol. 259, Is. 2, pp. 654-663, 2017.

[15] W.Y. Song, "Requirement management for product-service systems: Status review and future trends", COMPUTERS IN INDUSTRY, Vol. 85, pp. 11-22, 2017.

[16] O.S. V aidya, S. Kumar, "Analytic hierarchy process: An overview of applications", EUROPEAN JOURNAL OF OPERATIONAL RESEARCH, Vol. 169, Is. 1, pp. 1-29, 2006.

[17] D. Card, A.B. Krueger, "Myth and Measurement and the theory and Practice of Labor Economics", ILR REVIEW, Vol. 70, Is. 3, pp. 826831, 2017.

[18] G.A. Akerlof, R.E. Kranton, "Economics and identity", QUARTERLY JOURNAL OF ECONOMICS, Vol. 115, Is. 3, pp. 715-753, 2000.

[19] DellaVigna S., "Psychology and Economics: Evidence from the Field", JOURNAL OF ECONOMIC LITERATURE, Vol. 47, Is. 2, pp. 315$372,2009$.

[20] C.F. Camerer, R.M. Hogarth, "The effects of financial incentives in experiments: A review and capital-labor-production framework", JOURNAL OF RISK AND UNCERTAINTY, Vol. 19, Is. 1-3, pp. 7-42, 1999. 